Please note: this is a pre-print. The printed version will contain minor changes and corrections.

\title{
The Rhetoric of Catastrophe in Eleventh- Century Medieval Ireland: The Case of the SECOND VISION OF ADOMNÁN
}

\author{
Nicole Volmering
}

\begin{abstract}
Vae, uae, uae uiris Hiberniae insolae mandata Domini transgredientibus! Vae regibus et princi[pi]bus qui non di[1]igunt ueritatem et diligunt iniquitatem et rapinam! Vae doctoribus qui non docent ueritatem et consen[t]iunt uanitatibus imperfectorum! Vae meritricibus et peccatoribus qui sicut foenum et stipula concremabuntur a bura ignita in anno bisextili et embolesmi et in fine circuli et in Decollatione Iohannis Bautistae! IN sexta feria autem plaga conueni[e]t in illo anno, nisi deuota poenitentia prohibuerit, ut Níniuetae fecerunt! ${ }^{1}$
\end{abstract}

In modern colloquial usage, the terms apocalypse and catastrophe commonly go hand in hand. Modern conceptions of the term apocalypse incorporate not just the events of the Christian End Time, but also the end of the world in general, or catastrophic and irreversible damage to human civilization. The emphasis on disaster in these interpretations of apocalypse overshadows its original sense of "revelation" and betrays the lasting influence of the Book of Revelation, with its harrowing

${ }^{1}$ The Second Vision of Adomnan, ed. and trans. Nicole Volmering, "The Second Vision of Adomnán," in The End and Beyond: Medieval Irish Eschatology, ed. John Carey, Emma Nic Cárthaigh, and Caitríona Ó Dochartaigh (Aberystwyth: Celtic Studies Publications, 2014), 656-57: "Woe! Woe! Woe to the men of the island of Ireland transgressing the Lord's commandments! Woe to the kings and princes who do not love truth and love injustice and plunder! Woe to the teachers who do not teach truth and consent to the folly of the imperfect! Woe to the harlots and sinners who will be burned up like hay and stubble by a fire kindled in an embolismic leap year and at the end of a cycle and on the [Feast of] the Decollation of John the Baptist! On a Friday in this year a plague will come, unless devout penance will have prevented it, just as the Ninevites did!"

Catastrophes and the Apocalyptic in the Middle Ages and the Renaissance, ed. by Robert E. Bjork, ASMAR 43 (Turnhout: Brepols, 2019), pp. 1-14.

BREPOLS PUBLISHERS 
imagery of the events heralding the End Time, on Western thought. ${ }^{2}$ The relevance of these connotations for the present essay is two-fold. First, they color how we think about apocalyptic literature, whether ancient, medieval, or modern. ${ }^{3}$ Second, the association between catastrophe and apocalypticism is evident also in many medieval accounts speculating on the eschaton, the arrival of the Antichrist, or the meaning of celestial and environmental portents, but the correspondence between catastrophe and apocalypticism is a matter of degree and context. To an extent, then, this essay seeks to explore the question: when is a prophecy of catastrophe not apocalyptic?

In a narrow sense, apocalypticism is understood as a world of ideas similar to that which is found in apocalypses; ${ }^{4}$ but in this respect it must also be pointed out that apocalypses, as texts, are defined by more than their eschatological outlook. ${ }^{5}$ More often it is extended to refer to the anticipation of the imminent End Time, which will restore order to a world flawed or in crisis and which coincides with the hope of judgment, salvation, and transcendence. ${ }^{6}$ In addition, when speaking of apocalypticism in

${ }^{2}$ John J. Collins, "Apocalypse: An Overview," in Encyclopedia of Religion, ed. Lindsay Jones, Mircea Eliade, and Charles J. Adams, 2nd ed. (Detroit: Macmillan Reference, 2005), 409-14.

3 As Richard Landes has argued, a preoccupation with the "terrors" and fears perceived in apocalyptic literature, until recently, dominated discussions of works written around the turn of the first millennium, leading to a polarization into a pro- and anti-Terrors faction. See Richard Landes, "The Fear of an Apocalyptic Year 1000: Augustinian Historiography, Medieval and Modern," Speculum 75, no. 1 (2000): 97-145, here 97-101; and Landes, "The Terribles Espoirs of 1000 and the Tacit Fears of 2000," in The Apocalyptic Year 1000: Religious Expectation and Social Change, 950-1050, ed. Richard Landes, Andrew Gow, and David C. van Meter (Oxford and New York: Oxford University Press, 2003), 3-11.

${ }^{4}$ John Joseph Collins, Seers, Sybils and Sages in Hellenistic-Roman Judaism (Leiden: Brill, 1997), 27; Martin McNamara, "Apocalyptic and Eschatological Texts in Irish Literature: Oriental Connections?" in Apocalyptic and Eschatological Heritage: The Middle East and Celtic Realms, ed. Martin McNamara (Dublin: Four Courts Press, 2003), 76; Adela Yarbro Collins, "Apocalypse Now: The State of Apocalyptic Studies near the End of the First Decade of the Twenty-First Century," Harvard Theological Review 104, no. 4 (2011): 447-57, here 447-48. See also the overview of scholarship in Lorenzo DiTommaso, "Apocalypses and Apocalypticism I \& II," Currents in Biblical Research 5, no. 2 \& 3 (2007): 235-86, 367-432.

5 That is, apocalypses can be defined by a distinct combination of recurrent features typical of the genre. See John Joseph Collins, ed., Apocalypse. The Morphology of a Genre (Missoula, MT: Scholars Press, 1979); revisited in his "The Apocalyptic Genre," in The Apocalyptic Imagination: An Introduction to the Jewish Apocalyptic Literature, 2nd rev. ed. (Grand Rapids, MI: Eerdmans, 1998), 1-42; and David Hellholm, "The Problem of Apocalyptic Genre and the Apocalypse of John," in Early Christian Apocalypticism: Genre and Social Setting, ed. Adela Y. Collins (Decatur, GA: Scholars Press, 1986), 13-64.

${ }^{6}$ John Collins, "Apocalypse: An Overview," 410; Bernard McGinn, Visions of the End: Apocalyptic Traditions in the Middle Ages, 2nd ed. (New York: Columbia University Press, 1998), 3-4, 7-9. 
relation to medieval literature of the period concerning us here, often what is meant is millennialism (that is, anxiety concerning the approach of the turn of a millennium) ${ }^{7}$ as well as anxiety resulting from calendrical speculation regarding the approach or delay of the Day of Judgment. These must in turn be separated from a general awareness of living in the Last Age, which can be traced throughout the early Christian and medieval periods. Recent scholarship has suggested that a somewhat heightened, uneasy awareness of the potential relevance of millennial predictions derived from the Book of Revelation may be discerned in works from the tenth and eleventh centuries and may have underpinned a number of ostensibly or overtly apocalyptic moments and movements. To a degree, this apocalyptic anxiety may give rise to the interpretation of distressing environmental, celestial, or political events as apocalyptic portents, or it may lead to their reassessment in the light of apocalyptic history. ${ }^{8}$ While these preliminaries contextualize the complex association between prophecies of catastrophe and apocalypticism in medieval literature, this connection is sometimes hastily made, without regard to the relationship of such texts to the apocalyptic literature from which the term derives.

There certainly is no shortage of literary speculation on the events of the Last Days in medieval Irish literature, e.g., on the signs preceding Doomsday, ${ }^{9}$ or, for that matter, on related disasters predicted to befall the Irish before that time. Among the most well-known of these traditions are two prophecies of catastrophe, which have bearing on the subject of this essay. The first is the flood said to wipe out the Irish seven years ahead of Judgment Day so that they may be spared its tribulations; this was one of the favors granted to St. Patrick by the Lord. ${ }^{10}$ The

${ }^{7}$ I here follow Richard Landes in distinguishing the term from millenarianism or chiliasm (also frequently referred to as millennialism), which is the anticipation of a 1,000-year utopian period. See Landes, “The Fear," 101.

${ }^{8}$ McGinn, Visions of the End, esp. 28-36. However, McGinn points out (88-89) that this does not imply that apocalyptic hope in the tenth and eleventh centuries was especially fervent compared to other periods. See also Norman Cohn, The Pursuit Of The Millennium: Revolutionary Millenarians and Mystical Anarchists of the Middle Ages, rev. ed. (London: Pimlico, 1993); David C. van Meter, "Apocalyptic Moments and the Eschatological Rhetoric of Reform in the Early Eleventh Century: The Case of the Visionary of St. Vaast," in Landes, Gow, and van Meter, The Apocalyptic Year 1000, 311-25; David C. van Meter, "Selected Documents on Eschatological Expectations and Social Change around the Year 1000," in Landes, Gow, and van Meter, The Apocalyptic Year 1000, 337-45; and Mark Williams, Fiery Shapes: Celestial Portents and Astrology in Ireland and Wales 700-1700 (Oxford: Oxford University Press, 2010), 1-33.

9 See now all essays in "Part II: The Judgement and its Signs," in vol. 2 of John Carey, Emma Nic Cárthaigh, and Caitríona Ó Dochartaigh, The End and Beyond: Medieval Irish Eschatology. Cf. William W. Heist, The Fifteen Signs Before Doomsday (East Lansing: Michigan State College Press, 1952); and Martin McNamara, "The (Fifteen) Signs Before Doomsday in Irish Tradition," Miscellanea Patristica, Warszarwsie Studia Teologiczne 20, no. 2 (2007): 223-54.

${ }^{10}$ See e.g., Tirechán, Collectanea 52, ed. and trans. Ludwig Bieler, The Patrician Texts in the Book of Armagh, Scriptores Latini Hiberniae 10 (Dublin: Dublin Institute for Advanced Studies, 
second is the prophecy that a fiery plague, which will slay three-quarters ${ }^{11}$ of the Irish, will strike Ireland on the Feast of the Decollation of John the Baptist (29 August) because the Irish druid Mog Ruith killed John the Baptist. ${ }^{12}$ The text I wish to discuss in this essay, namely, a homily referred to as the Second Vision of Adomnán, ${ }^{13}$ draws on these traditions and takes as its starting point the prophecy printed above, which announces that the catastrophe will come when the Decollation of John of the Baptist falls on a Friday in an intercalary leap year at the end of a cycle. The homily tells us that it was revealed to St. Adomnán in a vision that the Irish would suffer this catastrophe as punishment for their sinful conduct. The text has an introduction in Latin, which provides the details for predicting the date of the catastrophe, and a shorter one in Irish, which details that only the mercy of God and St. Patrick will save them. It then outlines the catastrophe to come and the sins of the Irish. As a remedy for this situation, it then prescribes a series of commandments, most important among them a regular series of three-day fasts, to be held at the three Lents and, of course, at the Feast of the Decollation of John the Baptist. The text then concludes with a series of exhortative exempla to emphasize the efficacy of the recommended procedure.

The belief that the Feast of John the Baptist was unlucky is also corroborated by a set of annal entries for the year 1096, which record a great fear because the Feast was to fall on a Friday (see below) and provide details specifically associating it with the tradition represented in the Second Vision. For this reason, the text and the year 1096 have, on more than one occasion, been associated with apocalyptic or millennial fervor. Benjamin Hudson and Aideen O'Leary both place this event

1979), 165; the Vita Tripartita, ed. Kathleen Mulchrone, Bethu Phátraic: The Tripartite Life of Patrick (Dublin: Royal Irish Academy, 1939), 73-74; and the Vita Tripartita, ed. and trans. Whitley Stokes, The Tripartite Life of Patrick with Other Documents Relating to That Saint, 1st ed., Rerum Britannicarum Medii Aevi Scriptores 89 (London: H.M. Stationery Office, Eyre and Spottiswoode, 1887), 117-19.

${ }^{11}$ Or two-thirds in some texts, e.g., in The Beheading of John the Baptist by Mog Ruith §§4142, ed. and trans. Annie M. Scarre, "The Beheading of John the Baptist by Mog Ruith," Ériu 4 (1910): 173-81; and in the eschatological section of Immacallam in Dá Thuarad, ed. and trans. John Carey, "The End of the World in The Colloquy of the Trwo Sages," in Carey, Nic Cárthaigh, and Ó Dochartaigh, The End and Beyond, 629-45.

${ }^{12}$ Scarre, "The Beheading," §41-42; Käte Müller-Lisowski, ed. and trans., "Texte Zur Mog Ruith Sage," Zeitschrift für Celtische Philologie 14 (1923): 145-6.

${ }^{13}$ Volmering, "The Second Vision." Four known copies of this text survive, the earliest of which is contained in a fifteenth-century manuscript. The text itself, however, may be dated to the second half of the eleventh century. The copies are Dublin, Royal Irish Academy, MS $23 \mathrm{P}$ 16 (1230), pp. 258-59, dated ca. 1408-1411 (B, known as the Leabhar Breac); Dublin, Trinity College, MS 1317 (H.2.15b), pp. 137-53, ca. 1643 (T), a copy of B; Dublin, Royal Irish Academy, MS $23 \mathrm{O} 48$ (cat. 476), fol. 22r-v ( $F$, known as the Liber Flavus Fergusiorum), abridged; and Dublin, Royal Irish Academy, MS 24 P 9 (cat. 739), pp. 89-104 $\left(P^{9}\right)$, a freely adapted and modernized version of $B$. 
in the context of apocalypticism and institutional reform, and O'Leary goes so far as to argue that the legend of Mog Ruith mentioned above was the indirect cause of the panic of 1096. ${ }^{14}$ According to O'Leary, this event formed the height of an apocalyptic climax, which in turn catapulted the twelfth-century reform movement in Ireland. For this position, however, the evidence from the texts is largely lacking or circumstantial. By contrast, Elizabeth Boyle takes issue with this interpretation and argues that none of the vernacular eschatological homilies from the period 1000-1150 that she examines show any sign of anticipating an imminent apocalyptic judgment. In addition, she points out that the reform movement was well under way in Ireland by this time. She suggests, therefore, that the apocalyptic element in medieval Irish literature may have been overstated. ${ }^{15}$ In light of these contrasting opinions, it seems to me that we ought to revisit the crux of the discussion surrounding the Second Vision and the year 1096, namely, the association between catastrophe and apocalypticism and the anticipation of fear and hope that they arouse. Given that a widely recognized aspect of apocalypticism and apocalyptic rhetoric is its reactionary function as an expression of hope and fear in the face of an eschatological crisis, it seems worthwhile to examine the responses to the catastrophe associated with John the Baptist and what relationship, if any, these have to apocalypticism.

\section{Fear: The Feast of John the Baptist}

The Second Vision opens with the prognostication that the aforementioned catastrophe will take place on a Friday in a leap year with an intercalary moon, at the end of a cycle, and on the Decollation of John the Baptist. ${ }^{16}$ It furthermore describes the catastrophe as a fiery plague, which will cleanse Ireland from the southwest and consume three-fourths of the men of Ireland:

${ }^{14}$ Benjamin Hudson, "Time Is Short: The Eschatology of the Early Gaelic Church," in Last Things: Death and the Apocalypse in the Middle Ages, ed. Caroline Walker Bynum and Paul H. Freedman (Philadelphia: University of Pennsylvania Press, 2000), 101-23, 301-7; Aideen O'Leary, "Mog Ruith and Apocalypticism in Eleventh-Century Ireland," in The Individual in Celtic Literatures, ed. J.F. Nagy (Dublin: Four Courts Press, 2000), 51-60.

${ }^{15}$ Elizabeth Boyle, "The Rhetoric and Reality of Reform in Irish Eschatological Thought, c. 1000-c. 1150," History of Religions 55, no. 3 (2016): 268-88. In my own work on medieval Irish visions of the afterlife, I have likewise found that in such texts as Fis Adomnáin - the "first" vision of Adomnán - in which the Last Judgment lies at the center of its eschatological focus, there is no obvious indication of an imminent Doom, though the nature of this genre is such that the emphasis is on a different type of anticipation, that of an imminent individual judgment.

${ }^{16}$ The Second Vision of Adomnán \$1, in Volmering, "The Second Vision," 656: “. . in anno bisextili et embolesmi et in fine circuli et in Decollatione Iohannis Bautistae! IN sexta feria autem plaga conueni<e>t in illo anno..." 
IS dífaisnesi tra, 7 is dofulachtu in plág thicfa and mine-foichligther co lléir .i. lasar thened, luathaigther athach ngáithe glanfus Eirinn aniardes, 7 is 1 insin tene loiscfes teora cetraimi fer n-Erenn fri prapad súla, firu, mná, macu sceo ingena, cen chomand, cen cóibsin, cen sacarbaic. . . . Oen do cét dib namá dochumm nime ... ar bid tanaise do dígail lathi bratha in dígal dos-bera Dia for firu Erenn in amsir in dunibad-sin. ${ }^{17}$

That the Feast of John the Baptist is particularly inauspicious in the Irish tradition is reflected in a complex network of catastrophic portents said to take place on this day in the reign of Flann Cinach (or Cithach), the last king of Ireland, just prior to the Day of Judgment. The full extent of this tradition has not to date been adequately explored, ${ }^{18}$ but I discuss the most relevant texts here to illustrate the network of ideas to which the Second Vision is indebted.

As mentioned, the reason for the ill-fated character of this day is that the Irish druid Mog Ruith is held responsible for the killing of John the Baptist. It is uncertain precisely how old this belief is. The story is largely preserved in Middle Irish texts, but a reference to it already appears in the wisdom text Sanas Chormaic. ${ }^{19}$ It is also mentioned in a compilation of prophecies included in the commentaries to the Félire Oengusso concerning the scuab a Fanait [Broom out of Fánad], one of the manifestations in which the aforementioned catastrophe is attested. The account opens with the statement "Is i ndighail marbtha Eoin Bautist immorro tic in scuab a Fanait do erglanadh Erenn fri deredh in domain." ${ }^{20}$ There is an echo of the tradi-

17 The Second Vision of Adomnán \$5, in Volmering, "The Second Vision," 660: "It is unspeakable then, and unendurable, the plague which will come here, unless it is warded off diligently, that is, a flame of fire, as swift as a gust of wind which will cleanse Ireland from the southwest, and this is the fire which consumes three fourths of the men of Ireland in the blink of an eye, men, women, sons and daughters, without communion, without confession, without sacrament. Only one out of a hundred of them [will go] to heaven ... for second only to the punishment of Doomsday will be the punishment which God will bring down upon the men of Ireland at the time of that mortality."

18 Some of the relevant material was discussed in Eugene O'Curry, Lectures on the Manuscript Materials of Ancient Irish History (Dublin, 1861; Reprint, Dublin: Four Courts Press, 1995), lectures 18-21, esp. 384-85, 399-406, and 423-30, but this discussion is now outdated.

19 s.v. cnámchaill, in Paul Russell, Sharon Arbuthnot, and Pádraic Moran, Early Irish Glossaries Database (Cambridge: Department of Anglo-Saxon, Norse, and Celtic, 2010), http://www. asnc.cam.ac.uk/irishglossaries/. However, an earlier group of texts connecting Mog Ruith with Simon Magus appears to have no affiliation with the legends concerning the Feast of John the Baptist. See Käte Müller-Lisowski, "Texte”; and John Carey, "An Old Irish Poem about Mug Ruith," Journal of the Cork Historical and Archaeological Society 110 (2005): 113-34, here 125.

20 "In vengeance for the killing of John comes the Besom out of Fanait to expurgate Ireland at the end of the world." See Félire Óengusso, ed. and trans. Whitley Stokes, Félire Óengusso Céli Dé: The Martyrology of Oengus the Culdee, Henry Bradshaw Society 29 (London: Harrison and Sons, 1905; repr. Dublin: Dublin Institute for Advanced Studies, 1984), 190-91; and Scuap a 
tion represented by this account in one of the later manuscripts of the Second Vision $(F)$, the scribe of which felt spurred to insert into his copy of the text the phrase "ac sguabadh ${ }_{7}$ ac glanadh Eirenn" [sweeping and cleansing Ireland]. Other variants of the catastrophe include the roth rámach [rowing wheel] — an object closely associated with Mog Ruith, who constructed it ${ }^{21}$ — or the saighnen teintighi [fiery arrow], both of which are said to come sweeping across Ireland to lay waste a large part of its population. ${ }^{22}$ The overlap between the scuap and the saighnen is especially close, though they are separated in the sources. These portents are in turn often associated with the invasion of a large fleet at Inber Domnann (modern Malahide), also said to precede the Judgment. Only one of the texts describing these catastrophes, in addition to the Second Vision, explicitly notes that the Feast of John the Baptist must fall on a Friday. ${ }^{23}$ Most important for comparison with the Second Vision of Adamnan is the brief text known as the Lore of the Fiery Arrow or the Legend of Loch Bél Séad, which is preserved some fifteen pages before the Second Vision in the manuscript known as the Leabhar Breac. It describes a savage, flaming dragon which will only leave one-fourth of the Irish alive. It places the catastrophe in a leap year, five days after Easter, five years before the mortality (that is, Doomsday). The poem has significant verbal parallels with $\S \S 1$ and 5 of the Second Vision regarding the nature of the catastrophe and the calendrical details that predict its arrival. I have compared the two texts in extenso elsewhere and concluded that the author of the Second Vision appears to have drawn from this text at various points. ${ }^{24}$ Yet while both texts share the reference to a leap year, the notion that the year ought also to be embolismic is restricted to the Second Vision alone.

A comparison of these texts as a group shows that various motifs have become entwined with one another, but also that the events prophesied are consistently dated to a period leading up to Judgment Day, so that they may be placed firmly

Fánait, ed. and trans. Hugh Fogarty, "The Broom out Fánat," in Carey, Nic Cárthaigh, and Ó Dochartaigh, The End and Beyond, 685-96.

${ }^{21}$ E.g., Müller-Lisowki, “Texte," 158-63.

${ }^{22}$ The Lore of the Fiery Arrow, ed. and trans. John Carey, "The Lore of the Fiery Arrow," in Carey, Nic Cárthaigh, and Ó Dochartaigh, The End and Beyond, 705-13; Mesca Coluim Chille, ed. and trans. John Carey, "Colum Cille's Warning to Baíthín," in Carey, Nic Cárthaigh, and Ó Dochartaigh, The End and Beyond, 697-704; Longas Inbir Domnann, ed. and trans. Máire Herbert, "The Fleet of Inber Domnann," in Carey, Nic Cárthaigh, and Ó Dochartaigh, The End and Beyond, 715-20; and Immacallam in Dá Thuarad, ed. and trans. John Carey, "The End of the World," in Carey, Nic Cárthaigh, and Ó Dochartaigh, The End and Beyond, 629-45.

${ }^{23}$ Mesca Coluim Chille §61: "Tiucfa an feil Eoin ar aíne / da tiphraid oigh ilchaine / sirfe go Muir Torrian soir / ní fuigbe acht cetramad" [The feast of John will come on a Friday; on which young men will give many laments; It will reach as far as the Mediterranean; it will leave only a fourth alive].

${ }^{24}$ See the notes to $\$ 5$ in Volmering, "The Second Vision," 673-75. In $B$ - but not in the other known copy - the festival is said to fall on a Tuesday, but I am more inclined to consider the reading of the second copy original on the basis of the stylistic arrangement of the quatrain. 
within a "harbingers of Doom" tradition of which the Feast of John the Baptist is a notable element. In the Second Vision we are specifically told that the punishment that God will bring down on the men of Ireland will be "tanaise do dígail lathi brátha" [second [only] to the punishment of the Day of Judgment]. As in the other accounts, the predicted catastrophe is thus presented as a terrifying and finite event, inaugurating a period of irreversible destruction, but it is nevertheless still at least one step removed from Doomsday. Nor is this catastrophe equated with the flood that will cover Ireland seven years before Doom, an event from which it is usually separated. While all of the catastrophic events outlined above may be considered fixed future events in the Irish tradition, they are not datable in any precise way. Thus, it should come as no surprise that we find them complemented with calendrical speculation, as in the case of the Lore of the Fiery Arrow and the Second Vision of Adomnán. Like the events in Revelation, the precise date of these harbingers of doom remains elusive, dependent upon the recognition of obscure events or calculations, ${ }^{25}$ and yet, because of this, they naturally attract speculation.

The topic of calendrical speculation, then, brings us to the scare of the year 1096. Despite the detailed prognostication that opens the Second Vision, there is relatively little evidence for its import on the events of year 1096. I have shown elsewhere that the computistical information presented was inaccurate: that is, there is no year in the eleventh century that meets all of the requirements mentioned in the text. While the year 1096 was both embolismic and a leap year, the most important factor appears to have been that the Feast of John the Baptist fell on a Friday. ${ }^{26}$ The annals for this year record that there was a great fear as a consequence. ${ }^{27}$ It is

${ }_{25}$ Consider, e.g., the following obscure prognostication in the scuap a Fánait tradition ( $\left.\$ 6\right)$ : "in tan bus rēil ethur for Loch $\mathrm{Ru}[\mathrm{d}]$ raigei o dorus in praindtighe, as and do-thaot in Scuap" [when a boat is visible on Loch Rudraige from the door of the refectory, it is then that the Broom will come].

26 Volmering, "The Second Vision," 649-52.

27 The Annals of Loch Cé, ed. and trans. William M. Hennessy (London: Longman, 1871), 1096.4, and The Annals of Ulster, ed. and trans. Seán Mac Airt and Gearód Mac Niocaill (Dublin: Dublin Institute for Advanced Studies, 1983), 1096.3: "Uaman mór for Feruibh Erenn [uile] ria b-fhéil Eoin na bliadna sin" [Great terror over the men of [all] Ireland before the feast of John of this year]; The Annals of the Four Masters, ed. and trans. O'Donovan, John, Annala rioghachta Eireann: Annals of the Kingdom of Ireland, by the Four Masters, from the earliest period to the year 1616, 7 vols, 2nd ed. (Dublin: Hodges, Smith \& Co., 1856), 1096.9: "Feil Eóin for Aoine isin m-bliadhain-si. Ro ghabh imeagla mhór Fiora Ereann reimpi” [The festival of John fell on Friday this year; the men of Ireland were seized with great fear in consequence]; and the Chronicon Scottorum, ed. and trans. William M. Hennessy (London: Longman, 1866), 1096: "Bliadain na fele Eoin an bliadainsi for Aoine gur gab egla mor fir Erenn inte" [The year in which the feast of John fell on a Friday, and great fear seized the men of Ireland on account of it]. 
perhaps of interest in this respect that all texts that associate the Feast with Friday are dated to the Middle Irish period. ${ }^{28}$

There is one other aspect to the "John the Baptist" tradition not yet mentioned, which we find reflected in the Second Vision. The choice of St. Adomnán of Iona (ob. 704) as the visionary to whom the prophecy is attributed in the text is far from accidental, especially given that he plays no further role in the remainder of the text. St. Adomnán's association with visionary activities is not historical, but it is nevertheless also found in Fis Adomnáin (ca. 1000), in which the abbot is said to have gone out of his body on the Feast of John the Baptist in order to receive a vision of the afterworld, ${ }^{29}$ and in his Saint's Life (Betha Adomnáin, ca. 950). The Life explains that Adomnán was said to have foretold a calamity at the festival of St. John, but that this calamity was fulfilled by his own death on 23 September - the eve of the festival of the Nativity of John the Baptist. ${ }^{30}$ Adomnán's association, in these two texts, both with prophetic ability and with the Feast of John the Baptist make him an excellent candidate for a role as prophet alongside St. Colum Cille and St. Moling, two of the saints to whom the aforementioned prophecies are regularly ascribed.

The Second Vision, in ascribing the opening words printed at the start of this essay to Adomnán, thus draws on a set of motifs concerning, on the one hand, the catastrophic events heralding Doomsday and, on the other, the death of one of Ireland's most famous saints - all concentrating on the date of John the Baptist. These references would hardly be lost on a contemporary audience. In doing so, it initiates a discourse of fear, which in turn requires a discourse of hope.

${ }^{28}$ That is, the Second Vision, the Mesca Coluim Chille, and the sole quatrain of the latter that is included in the commentaries to the Félire Oengusso (for which see Stokes, Félire, 190-91).

${ }^{29}$ Fis Adomnáin $\$ 10$, ed. and trans. John Carey, "Fís Adomnáin," in Apocrypha Hiberniae II: Apocalyptica 2, ed. Martin McNamara (forthcoming): "Ro foillsiged dano fo deóid do Adamnán ua Thinne, do ardecnaid iarthair domain, aní pritchaither sunn, diaro escomla a ainimm asa churp i féil Iohain Bauptaist ${ }_{7}$ dia rucad dochum ríchid co n-ainglib nime ${ }_{7}$ ifirn cona doescursiluag" [Finally, moreover, that which is preached here was revealed to Adomnán grandson of Tinne, to the high scholar of the west of the world, when his soul passed out of his body on the feast of John the Baptist, and when it was borne to heaven with the angels of heaven, and to hell with its rabble host].

${ }^{30}$ Betha Adamnáin, ed. and trans. Máire Herbert and Pádraig Ó Riain, Betha Adamnáin: The Irish Life of Adamnán (London: Irish Text Society, 1988), 85; Thomas Owen Clancy, "Adomnán in Medieval Gaelic Literary Tradition," in Adomnán of Iona: Theologian, Lawmaker, Peacemaker, ed. J.M. Wooding et al. (Dublin: Four Courts Press, 2010), 121. 


\section{Hope: Spiritual Direction and Penance}

Having established the nature of the catastrophe, the Second Vision proceeds to outline the reasons for it and the remedy proposed to avert it. In this part of the text, Ireland's patron saint, Patrick, is the protagonist. Earlier in the text the reader is told that Patrick is the only saint not pleading against the people of Ireland and that his intercession is necessary for averting the plague. His inclusion here is a reference to Patrick's special status as judge of the Irish on Doomsday-another favor he obtained from the Lord, as recorded by his hagiographers. ${ }^{31}$ In paragraph six we are told specifically that the catastrophe will be brought upon the Irish because of dith [lack, destruction] of faith and worship in Ireland "amal ro fácaib Patraic leo" [as Patrick had left it with them], that is, when he converted the Irish and gave them the Faith. Instead, the Irish now appear to have reverted to paganism and are accused of committing every evil, apart from worshipping idols. ${ }^{32}$ In other words, they have broken Patrick's law. Paragraph seven, then, offers the remedy: the catastrophe can only be averted by obtaining God's mercy on account of renewing one's faith and through Patrick's prayer to the Lord. This is followed by a detailed exposition that makes up one of the largest sections of the text, on the "law of spiritual direction" commanded by God and Patrick in order to successfully ward off the catastrophe.

The legal undertones of the previous sections are made abundantly clear here. The people of Ireland are given a set of commands, whose fulfillment is, in accordance with early Irish legal practice, secured through the means of guarantors. Strikingly, the guarantors in question are St. Peter, the Virgin Mary, and the archangel Michael. ${ }^{33}$ The commands include "a three-day fast every three months; and 'making smooth from rough'; and two ordained men in every church of God for baptism, communion and singing requiems; and boys for studying; and Sunday free." ${ }^{4}$ The three-day fast envisioned here is quite strict, as it involves three days and nights without food or drink, rather than the more regular allowance of one

31 Vita Tripartita, ed. Stokes, The Tripartite Life (see above, n. 10).

32 The Second Vision of Adomnán §§6-7, in Volmering, "The Second Vision."

33 I have not been able to find a parallel elsewhere for this triad of guarantors, but it is likely inspired by their role as intercessors elsewhere, in versions of the Transitus Mariae. See notes to The Second Vision of Adomnán §8, in Volmering, "The Second Vision." Alternatively, the text may here have been inspired by the Cain Adomnán \$22, ed. and trans. Kuno Meyer, Cáin Adomnáin: An Old-Irish Treatise on the Law of Adamnan (Oxford: Clarendon, 1905), in which Adomnán's law is secured with guarantors (ráthai), which include no less than the sun and moon and all other elements of God; Peter, Paul, Andrew, and the other apostles; Gregory; the two Patricks; and some thirty Irishmen, among whom bishops and abbots.

34 The Second Vision of Adomnán §8, in Volmering, "The Second Vision": "tredan cecha tremsi, ${ }_{7}$ denum redi do amrédib ${ }_{7}$ dias cech eclasi De, do æs graid fri bathis ${ }_{7}$ comaind ${ }_{7} \mathrm{~g}<\mathrm{ab}>$ ail n-ec[n] arci ${ }_{7}$ maccu do legend ${ }_{7}$ soire domnaig." 
meal per day. It is prescribed for the beginning of the winter Lent; the Wednesday after the beginning of the spring Lent; the Wednesday after Pentecost, and the Wednesday after the beginning of autumn, in addition to fasting on the Feast of John. There are, in addition, penalties for those who refuse, although provision is made to exempt sick people, infants, and old people. This part of the text, therefore, presents the fast as if it was canon law but places it in the context of eschatological justice. Patrick's law is presented as the spiritual order that has been broken but that can be restored if the Irish make an effort to renew their faith by accepting these new commandments.

Each of the two protagonists in this text has been awarded a distinct role. Adamnán is the messenger delivering the warning; he functions as the authoritative source, modeled on the biblical prophets. Patrick's role, by contrast, is both that of eschatological judge and that of guardian of the divine law on earth. When his law is violated and his people are on the brink of catastrophe, he is the only one who can obtain grace on their behalf. It is through acceptance of his commandments that the balance may be restored and the plague may be warded off. This emphasis on the law and on the commandments is hardly accidental. The author is creating a deliberate parallel with Moses. Our text here draws on earlier hagiography, in particular the Vita Tripartita, a lengthy work on Patrick written at the center of his cult, in Armagh. In this work, as previously mentioned, Patrick obtains favors from the Lord by fasting against him - a legal procedure in medieval Ireland - on top of a mountain, "after the manner of Moses son of Amra, for they were alike in many things." ${ }^{35}$ Patrick is thus presented as the Irish Moses. Indeed, the promise that everything can be obtained by asking it of God and Patrick through fasting and prayer is followed by a series of five Old Testament exempla demonstrating the efficacy of fasting and prayer. The first of these recalls Moses' fast on Mount Sinai without food or drink in Exodus and his ability to lead God's people through the Red Sea. The analogy with Patrick's task of leading the Irish out of danger is obvious. Other examples include Joshua's defeat of the tribes of Canaan through prayer, Jonas' escape from the belly of the whale, and the release of the three boys from the fiery furnace. We may observe, then, that the catastrophe here foretold is presented, much in the tradition of the Old Testament, as a punishment for the sinful. ${ }^{36}$ Yet while the text laments a world filled with sin and injustice, it anticipates its restoration to spiritual order and exhorts its audience to fasting and prayer.

The annals record a similar approach; similar enough, in fact, that we cannot be sure that one was not based on the other. The variation is in the details rather than the approach: one entry records that the three-day fast was held every month rather than at the three Lents and the Feast of John the Baptist, as in our text. In

${ }^{35}$ Vita Tripartita, in Stokes, The Tripartite Life, 115.

${ }^{36}$ In fact, the text alludes to this in paragraph six. 
addition, it prescribes daily fasting for a year and alms-giving. ${ }^{37}$ Thus, while they cannot be equated with the Second Vision without question, the annals provide a historical basis to the 1096 scare and underscore that an active effort was made in that year to prevent the calamity by prescribing, like in the Second Vision, a remedy of prayer and fasting. The most significant element arising from the extant record is perhaps that the information mainly survives in annals generally associated with the vicinity of Armagh. In close analogy with the Second Vision, the annals underscore that the comarb [ecclesiastical successor] of Patrick was in charge of the implementation of a reforming rule designed to deal with the fear described. Whether or not this was a nation-wide program may yet be called into question somewhat by the absence of relevant records in, for instance, The Annals of Inisfallen. ${ }^{38}$

\section{An Apocalyptic Message?}

So what do the Second Vision and these annal references have to do with apocalypticism? The text only counts a number of aspects that might in one way or another be associated with apocalypticism or apocalyptic rhetoric. The text opens with a revelation to an authoritative prophet by an angel. The angel's words "Vae, uae, uae uiris Hiberniae . . . " even echo the phrase "Vae, vae, vae habitantibus in terra ... !" from Revelation 3:18. And, of course, it places itself firmly in a tradition of Irish apocalyptic portents in which St. Patrick reigns as eschatological Judge. The text thus draws freely from available apocalyptic imagery in order to create its argument yet does not have a strictly apocalyptic outlook. The text is concerned with the flaws of the contemporary world but does not anticipate that this flawed world be overthrown in its entirety and replaced with a utopian land of saints. Rather, it argues for a more personal type of reform, a reconversion in fact. The threatening catastrophe is presented as a form of punishment, as vengeance even, for the sins of the Irish, but it is not equated with the Final Judgment. The Second Vision presents a narrative which inspires action, but at no point is its argument hysterical or even urgent. Much like the poetic works from which it draws, its rhetoric is designed to be emotive, calling up images of terror. But like Revelation, it plays out a drama ${ }^{39}$

37 Chronicon Scottorum, 1906: "conidh í comairle ar ar cinnettur clerigh Erenn da dichor.i. tredenus gach mí trosgadh gach laoi go cenn mbliadhna ${ }_{7}$ almsana don Coimdhedh" [and what the clerics of Ireland resolved on to dispel it was that there should be a three-days fast each month and abstention every day for a year and alms [should be given] to the Lord].

38 The Annals of Tigernach, moreover, only refer to 1096 as a bad year, without additional detail. Yet, that the comarb of Patrick went on a circuit of Munster in 1094 suggests that Armagh was attempting to establish its authority there.

39 On Revelation as a drama, see the remarks in McGinn, Visions of the End, 31-36; and Stephen D. O'Leary, Arguing the Apocalypse: A Theory of Millennial Rhetoric (Oxford: Oxford University Press, 1994), esp. chap. 3. 
leading its audience from fear into hope by providing them, not with images of the Kingdom Come, but of a clear path towards penance and faith.

While the tone of our text is decidedly pragmatic and reformist, the annals, in contrast, do appear to suggest fear of an imminent catastrophe on the Feast of John. Placed against the wider background of traditions surrounding the Feast of John the Baptist, it does not seem altogether unlikely that the prognostication might have inspired fear. But it is unlikely to have been an apocalyptic fear. Rather, I think the events recorded for 1096 are perhaps better regarded as an a posteriori reaction - in the words of Bernard McGinn — to environmental upheaval. ${ }^{40}$ The Second Vision specifically indicates that the Feast of John itself will also be preceded by a number of plagues. If this belief was indeed current in the late eleventh century, the combination of recurrent environmental disasters and a severe plague in the years preceding $1096^{41}$ with prognostications regarding the Decollation may have led to the reinterpretation of such current events by writing them into God's divine plan and making them part of the larger narrative of sin and penance. If, like in the Second Vision, or, for that matter, biblical history in general, catastrophe is to be equated with divine vengeance, then its avoidance surely lies in removing the offence. A program of increased devotional activity fits that paradigm. Such a response is neither unusual nor uncommon and is, in fact, of a similar fabric to many apocalyptic moments inspired by political or environment upheaval. ${ }^{42}$ The rhetoric of the Second Vision is carefully woven around existing images of judgment and justice, yet its aspirations are decidedly earthly. As a result, it is able to transform its prophecy of doom into a reform-inspiring rhetoric of catastrophe.

${ }^{40}$ McGinn, Visions of the End, 33.

${ }^{41}$ Volmering, "The Second Vision," 651-52; Boyle, "Rhetoric and Reality."

${ }^{42}$ Van Meter, "Selected Documents," 337-45; McGinn, Visions of the End, 89. 


\section{Table of Contents}

Introduction vii ROBERT E. BJORK

The Rhetoric of Catastrophe in Eleventh-Century Medieval Ireland:

The Case of the Second Vision of Adomnán NICOLE VOLMERING

The Virgin Mary and the Last Judgment in the Old Norse-Icelandic Maríu saga DANIEL NAJORK

Personalized Eschatology and Lorraine Apocalypses, ca. 1295-1320 KARLYN GRIFFITH

William Langland's Uncertain Apocalyptic Prophecy of the Davidic King KIMBERLY FONZO

Res papirea and the Catastrophic Arrival of the Antichrist ALISON BERINGER

Consider this Tomb: An Unedited Italian Sonnet about Death and Final Judgment FABIAN ALFIE

“The Lesser Day of Resurrection": Ottoman Interpretations of the Istanbul Earthquake of 1509 ERDEN CIPA

Pieter Bruegel's Towers of Babel: Spirals toward Destruction CATHERINE SHULTZ MCFARLAND

Inhuman Rage: Linguistic Apocalypse in a Sixteenth-Century Huguenot Poetic Commemoration of the Sack of Lyon EVAN J. BIBBEE

Fire in the Sky: Celestial Omens of Catastrophe in a French Renaissance

Painting KATRINA KLAASMEYER 
The Wrath of God and the Soul on Trial: Late Medieval and Puritan

Eschatological Fears and the Clerical (Ab)use of Apocalyptical Imagery JOANNA LUDWIKOWSKA

The Apocalyptic Legacy of Pseudo-Ephraem in Russia: The Sermon on the Antichrist

EUGENE CLAY 